\title{
THE EFFECT OF MASSAGE STIMULATION ON THE GENERAL MOVEMENTS QUALITY IN BREASTFED PRETERM INFANT
}

\author{
Elizabeth Beatrice Jonathan, Ahmad Suryawan, Mira Irmawati \\ Department of Child Health, Dr. Soetomo Hospital, Faculty of Medicine, Universitas Airlangga, Surabaya, \\ Indonesia
}

\section{ABSTRACT}

\begin{abstract}
General movements (GMs) assessment is one of the modalities to detect abnormal infant development early, the examination of preterm infant development is very important. Preterm infant has a long-term health impact and the risk of neonatal morbidity and mortality, need breast milk as the best nutrition and also need stimulation, one of which is massage. This study aim to analyze massage stimulation effect on the general movements in breastfed preterm infant in Dr. Soetomo Hospital, Surabaya. A randomize control group pre-test post-test design was conducted on preterm infant, 39 babies were enrolled. Massage stimulation was done for 10 consecutive days 3 times in the neonatal ward while observing the condition. The quality assessment of GMs is according to the standardization of the Prechtl method, through two stages, taking video recording and editing GMs, and analysis the video recordings of GMs. Statistical by comparison test. The quality of preterm GMs in massage group (85.7\%) and control group (69.6\%) with $p=0.287$. The quality of GMs writhing in the massage group was dominated by abnormal GMs (65\%), in control group were dominated by normal (63.2\%) with $p=0.150$. In the fidgety GMs, the massage group (75\%) and not massage (78.9\%) were dominated by normal GMs, with $p=1.000$. There were no differences in the quality of preterm GMs, writhing GMs and fidgety GMs for preterm infants in both group.
\end{abstract}

Keywords: Preterm; low birth weight; massage, breastfed; general movements

\section{ABSTRAK}

General movements (GMs) merupakan salah satu modalitas mendeteksi gangguan perkembangan bayi secara dini sehingga pemeriksaan perkembangan bayi prematur sangat penting. Oleh karena, bayi prematur memiliki dampak jangka panjang kesehatan maupun risiko morbiditas dan mortalitas. Air susu ibu (ASI) merupakan nutrisi penting bagi bayi prematur selain stimulasi, salah satunya adalah pijat. Tujuan penelitian ini adalah menganalisis pengaruh pijat terhadap kualitas general movements bayi prematur ASI di RSUD Dr.Soetomo Surabaya. Rancangan randomized control group pre-test post-test pada bayi prematur, bulan Februari-November. Sebanyak 39 bayi dianalisis. Pijat dilakukan selama 10 hari berturut-turut, 3 kali sehari di neonatal intermediate dan nicu IRD dengan mengamati kondisi bayi. Penilaian kualitas GMs menggunakan standardisasi metode Prechtl, melalui dua tahap, mengambil rekaman video dan mengedit GMs, dan menganalisis rekaman video GMs. Statistik dengan uji komparasi. Kualitas GMs preterm kelompok pijat (85,7\%) dan tidak pijat (69,6\%) dengan $p=0,287$. Kualitas GMs writhing kelompok pijat didominasi abnormal GMs (65\%), pada kelompok tidak pijat didominasi normal GMs $(63,2 \%)$ dengan $p=0,150$. GMs fidgety, kelompok pijat $(75 \%)$ dan tidak pijat $(78,9 \%)$ didominasi normal GMs, dengan $p=1.000$. Tidak terdapat perbedaan kualitas GMs preterm, GMs writhing dan GMs fidgety pada kedua kelompok.

Kata kunci: Prematur; berat badan lahir rendah; pijat; air susu ibu; general movements

Correspondence: Ahmad Suryawan, Jl. Prof. Dr.Moestopo no.6-8. Surabaya, Department of Child Health Faculty of Medicine, Universitas Airlangga/Dr.Soetomo Hospital Surabaya, Indonesia. Phone: +6281553810009.

E-mail: ahmad.suryawan@fk.unair.ac.id

pISSN:2355-8393 • eISSN: 2599-056x • doi: http://dx.doi.org/10.20473/fmi.v56i4.23416

- Fol Med Indones. 2020;56:302-308 • Received 14 Jun 2019 • Accepted 12 Dec 2019

- Open access under CC-BY-NC-SA license • Available at https://e-journal.unair.ac.id/FMI/

\section{INTRODUCTION}

Preterm infants are babies born less than 37 weeks of gestation from the first day of the last menstruation, where premature babies have a long-term health impact and the risk of neonatal morbidity and mortality (WHO 2012). Indonesia is the ninth in the world, more than
$15 \%$ of babies are born prematurely each year (WHO 2012). Preterm are at risk more than 50\% for neurobehavioral disorders, such as motor incoordination, cognitive impairment, attention disorders, and behavioral disorders (Anderson \& Doyle 2003). Optimal nutrition for preterm infants aims to match the rate of growth in the uterus. Breast milk is the 
best food for newborns, both term or preterm (Underwood 2013).

Preterm infant need stimulation, one of which is massage (Field 2014). Massage stimulation is the initial form of communication that we have with babies, which combines aspects of closeness, eye contact, smiling and facial expressions (Lee 2005). Some meta-analysis studies, $72 \%$ of preterm infant who were massaged, gave positive reactions in terms of optimizing growth and development (Field 2014, Diego et al 2007).

The assessment of General Movements (GMs) is one of the modalities to detect abnormal infant development early so that the examination of the development of preterm infant is very important (Khan et al, 2014). The abnormalities of GMs show subplate dysfunction and efferent motor system connections in the brain and are at high risk of cerebral palsy or minor neurological dysfunction (MND), attention deficit hyperactive disorders (ADHD) as well as cognitive problems at school age (Algra 2007, Hadders-Algra 2004).

General movements (GMs) has good validity to predict the risk of a child's developmental disorder (Suryawan et al 2008). The first 2 to 4 months of life have been shown to have a very high predictive value with a sensitivity of $94.5 \%$ and a specificity of $85 \%$ (Einspieler $\&$ Prechtl 2005). The quality of GMs in newborn babies in Indonesia were predominantly abnormal, where high risk of developmental disorder at a later time. And also lower birth weight more likely shows abnormal GMs (Suryawan et al 2008). The aim of this study is to analyze massage effect in general movements of breastfed preterm in Dr. Soetomo Hospital Surabaya.

\section{MATERIALS AND METHODS}

The research conducted is part of the study "The effect of massage on preterm infants who are breastfed". Experimental, with a research design using randomize control group pre-test post-test design. The sampling was completed based on total sampling with consecutive sampling techniques, divided to massage and control group, through various inclusion criteria (preterm infants born at the age below 37 weeks of pregnancy in RSUD Dr. Soetomo who received breast milk, birth body weight less than 2500 grams, babies and parents living in Surabaya, babies in good condition, parents are willing to sign an informed consent to take part in the study) and exclusion (infants with congenital abnormalities, infants who need surgery, experience poor conditions so that they need a ventilator aid, parents or guardians refuse to be included in this study. Drop out criteria include: parents withdraw from research participation, die before completing the three recording periods of GMs, missing from observation because they moved to an unknown location, GMs record cannot be evaluated.

Massage stimulation was done for 10 consecutive days 3 times in the neonatal ward while observing the condition. The quality assessment of GMs is according to the standardization of the Prechtl method, through two stages, taking video recording and editing GMs, and analysis the video recordings of GMs. Both group will recording for preterm GMs from 28 weeks to $36 / 38$ weeks, writhing GMs from $36 / 38$ weeks to $46 / 52$ weeks and fidgety from $46 / 52$ to $54 / 58$ weeks. Recording of preterm period babies in the neonate section Dr. Soetomo Hospital Surabaya, the writhing and fidgety period was carried out during outpatient clinic or with home visit. Statistical analysis of Chi-square, Fisher's exact, Independent T-test, and Mann-Whitney U test were used with $p$-value of $<0.05$ being significant. The Research Ethics Committee of the Dr. Soetomo Hospital, Surabaya, approved this study.

\section{RESULTS}

A total of 44 babies were included during this study period, 21 babies were intervened and 23 babies were controls. Both groups were examined by anthropometry and preterm GMs. During the writhing period there were 2 babies lost-of-observation infants, 1 baby was excluded because it was found with congenital abnormalities (hydrocephalus) and 1 baby died in the not massage group and 1 baby died in the massage group. From 44 babies there were 39 babies were examined for anthropometry and recording writhing GMs. This amount were same at the end of the observation, which is carried out by anthropometric and fidgety GMs. Some videos in this study that were not technically feasible were not analyzed.

Table 1 shows the characteristic subjects, where gestational age were not significantly difference in both groups and also the others characteristics. Only mother educational level was significantly with $\mathrm{p}=0.007$. Meanwhile, Prenatal, perinatal and pasca-natal characteristics were not significantly difference in both groups, shows in Table 2. 
Table 1. General characteristics of research subjects

\begin{tabular}{|c|c|c|c|}
\hline Characteristics & $\begin{array}{c}\text { Massage } \\
\mathrm{n}=20\end{array}$ & $\begin{array}{c}\text { Control } \\
\mathrm{n}=19\end{array}$ & $\mathrm{P}$ \\
\hline \multicolumn{4}{|l|}{ General characteristics } \\
\hline Gestational age, average (SD) & $33.1(1.972)$ & $32.96(2.033)$ & $0.820^{(3)}$ \\
\hline Pregnancy, average (SD) & $2.81(2.015)$ & $2.35(1.695)$ & $0.414^{(3)}$ \\
\hline \multicolumn{4}{|l|}{ Anthropometry at birth, mean (SD) } \\
\hline Birth weight & $1629.29(395.450)$ & $1661.09(425.612)$ & $0.799^{(3)}$ \\
\hline Birth length & $42.62(3.584)$ & $41.61(3.726)$ & $0.366^{(3)}$ \\
\hline Head circumference is born & $29.05(2.156)$ & $29.48(2.042)$ & $0.500^{(3)}$ \\
\hline Age gets breast milk, average (SD) & $4.10(4.10)$ & $4.35(4.35)$ & $0.775^{(3)}$ \\
\hline Length of stay, average (SD) & $19.43(10.661)$ & $16.52(13.055)$ & $0.426^{(3)}$ \\
\hline \multicolumn{4}{|l|}{$\begin{array}{l}\text { Age of infants when recorded GMs, } \\
\text { week (mean }(\mathrm{SD}) \text { ) }\end{array}$} \\
\hline Preterm GMs period & $34.95(1.658)$ & $34.57(1.472)$ & $0.416^{(3)}$ \\
\hline Writhing GMs period & $42.40(1.603)$ & $42.16(1.675)$ & $0.647^{(3)}$ \\
\hline Fidgety GMS period & $55.55(1.731)$ & $55.32(1.600)$ & $0.648^{(3)}$ \\
\hline \multicolumn{4}{|l|}{ Gender, n (\%) } \\
\hline Boy & $9(42.9)$ & $10(43.5)$ & $1.000^{(1)}$ \\
\hline Girl & $12(57.1)$ & $13(56.5)$ & \\
\hline \multicolumn{4}{|l|}{ Father's job, n (\%) } \\
\hline Work & $21(100)$ & $22(95.7)$ & $1.000^{(2)}$ \\
\hline Does not work & $0(0)$ & $1(4.3)$ & \\
\hline \multicolumn{4}{|l|}{ Father's education, $\mathrm{n}(\%)$} \\
\hline Elementary school & $0(0)$ & $3(13.0)$ & $0.117^{(4)}$ \\
\hline Junior high school & $3(14.3)$ & $2(8.7)$ & \\
\hline High school & $10(47.6)$ & $14(60.9)$ & \\
\hline Academy & $1(4.8)$ & $1(4.3)$ & \\
\hline Bachelor & $7(33.3)$ & $3(13.0)$ & \\
\hline \multicolumn{4}{|l|}{ Mother's job, n (\%) } \\
\hline Work & $11(52.4)$ & $7(30.4)$ & $0.241^{(1)}$ \\
\hline Does not work & $10(47.6)$ & $16(69.6)$ & \\
\hline \multicolumn{4}{|l|}{ Mother's education, $\mathrm{n}(\%)$} \\
\hline Elementary school & $0(0)$ & $3(13.0)$ & $0.007^{(4)}$ \\
\hline Junior high school & $3(14.3)$ & $2(8.7)$ & \\
\hline High school & $7(33.3)$ & $15(65.2)$ & \\
\hline Academy & $0(0)$ & $2(8.7)$ & \\
\hline Bachelor & $11(52.4)$ & $1(4.3)$ & \\
\hline \multicolumn{4}{|l|}{ Family income, n (\%) } \\
\hline$<650,000$ & $0(0)$ & $1(4.3)$ & $0.591^{(4)}$ \\
\hline $650,000-1,300,000$ & $1(4.8)$ & $1(4.3)$ & \\
\hline $1,300,000$ & $20(95.2)$ & $21(91.3)$ & \\
\hline \multicolumn{4}{|l|}{ Number of families in house, $\mathrm{n}(\%)$} \\
\hline One family & $9(42.9)$ & $11(47.8)$ & $0.978^{(1)}$ \\
\hline More than one family & $12(57.1)$ & $12(52.2)$ & \\
\hline \multicolumn{4}{|l|}{ Home ownership, n (\%) } \\
\hline One's own & $6(28.6)$ & $3(13.0)$ & $0.138^{(4)}$ \\
\hline Family owned & $11(52.4)$ & $12(52.2)$ & \\
\hline Belongs to other people (rent) & $4(19.0)$ & $8(34.8)$ & \\
\hline
\end{tabular}

Note: 1). Chi-square; 2). Fisher's exact; 3). Independent T-test; 4). Mann-Whitney U test

From the statistical analysis found body weight was not significantly difference in massage and control groups in the beginning of observation (birth and preterm period), during observation (writhing period) body weight in massage group was higher (3236.50 (666.043) gram) than control group (3096.84 (591.834) gram), at the end of observation (fidgety period) body weight in massage group also was higher $(5727,00(843,171)$ gram) than control group (5494.74 (1092.410) gram) are shown in Table 3. Body length and head circumference in both groups were not significantly difference either at the beginning, during and the end of observation (Table $3)$. 
Table 2. Prenatal, perinatal and pasca-natal characteristics

\begin{tabular}{|c|c|c|c|}
\hline Characteristics & $\begin{array}{c}\text { Massage } \\
\mathrm{n}=20\end{array}$ & $\begin{array}{c}\text { Control } \\
\mathrm{n}=19\end{array}$ & $\mathrm{P}$ \\
\hline \multicolumn{4}{|l|}{ Prenatal } \\
\hline $\begin{array}{l}\text { History of illness during pregnancy, n (\%) } \\
\text { Bad events during pregnancy, n (\%) } \\
\text { Never give birth less months, n (\%) } \\
\text { Drinking pregnant milk, n (\%) } \\
\text { Pre-eclampsia / eclampsia, n (\%) }\end{array}$ & $\begin{array}{l}10(47.6) \\
3(14.3) \\
3(14.3) \\
13(61.9) \\
6(28.6)\end{array}$ & $\begin{aligned} 10 & (43.5) \\
2 & (8.7) \\
2 & (8.7) \\
19 & (82.6) \\
6 & (26.1)\end{aligned}$ & $\begin{array}{l}1.000^{(1)} \\
0.658^{(2)} \\
0.658^{(2)} \\
0.230^{(1)} \\
1.000^{(1)}\end{array}$ \\
\hline \multicolumn{4}{|l|}{ Perinatal } \\
\hline $\begin{array}{l}\text { Type of labor, } \mathrm{n}(\%) \\
\quad \text { Spontaneous } \\
\quad \text { Caesarean section } \\
\text { Asphyxia, n (\%) } \\
\text { Difficulty in labor, n (\%) } \\
\text { High risk of labor } \\
\text { Premature rupture of membranes, n (\%) } \\
\text { Jaundice, n (\%) } \\
\text { Hypoglycemia, n (\%) } \\
\text { Sepsis, n (\%) }\end{array}$ & $\begin{array}{c}9(42.9) \\
12(57.1) \\
0(0) \\
9(42.9) \\
12(57.1) \\
11(52.4) \\
13(61.9) \\
0(0) \\
1(4.8)\end{array}$ & $\begin{array}{c}6(26.1) \\
17(73.9) \\
1(4.3) \\
12(52.2) \\
17(73.9) \\
11(47.8) \\
12(52.2) \\
1(4.3) \\
0(0)\end{array}$ & $\begin{array}{l}0.588^{(1)} \\
1.000^{(2)} \\
0.752^{(1)} \\
0.393^{(1)} \\
1.000^{(1)} \\
0.729^{(3)} \\
1.000^{(2)} \\
0.477^{(2)}\end{array}$ \\
\hline \multicolumn{4}{|l|}{ Pasca-natal } \\
\hline $\begin{array}{l}\text { Nutrition intake, } \mathrm{n}(\%) \\
\text { Exclusive breastfeeding } \\
\text { Dominant breast milk } \\
\text { Dominant formula }\end{array}$ & $\begin{array}{l}6(30.0) \\
6(30.0) \\
8(40.0)\end{array}$ & $\begin{array}{l}3(15.8) \\
6(31.6) \\
10(52.6)\end{array}$ & $0.318^{(4)}$ \\
\hline $\begin{array}{l}\text { Main Caregiver, } \mathrm{n}(\%) \\
\text { Mother (parent) alone } \\
\text { Family (grandfather, grandmother, etc.) } \\
\text { Maid } \\
\text { Others }\end{array}$ & $\begin{array}{c}15(75.0) \\
2(10.0) \\
0(0) \\
3(15.0) \\
1(5.0)\end{array}$ & $\begin{array}{l}13(68.4) \\
6(26.3) \\
1(5.3) \\
0(0) \\
2(10.5)\end{array}$ & $0.873^{(4)}$ \\
\hline History of admission, n (\%) & & & \\
\hline
\end{tabular}

Note: 1). Chi-square; 2). Fisher's exact; 3). Independent T-test; 4). Mann-Whitney U test

Table 3. Anthropometric differences in massage and control groups

\begin{tabular}{lccc}
\hline \multicolumn{1}{c}{ Group } & Massage & Control & p value \\
& & & 0.799 \\
Birth weight, mean (SD) gram & $1629.29(395.450)$ & $1661.09(425.612)$ & 0.366 \\
Birth length, mean (SD) cm & $42.62(3.584)$ & $41.61(3.726)$ & 0.500 \\
Head circumference, mean (SD) cm & $29.05(2.156)$ & $29.48(2.042)$ & 0.603 \\
Weight, mean (SD) gram & $1687.67(290.477)$ & $1738.00(342.068)$ & 0.814 \\
Length, mean (SD) cm & $43.38(3.263)$ & $43.13(3.706)$ & 0.352 \\
Head circumference, mean (SD) cm & $30.12(1.816)$ & $30.59(1.474)$ & 0.494 \\
Weight, mean (SD) gram & & & 0.513 \\
Length, mean (SD) cm & $3236.50(666.043)$ & $3096.84(591.834)$ & 0.362 \\
Head circumference, mean (SD) cm & $50.10(3.007)$ & $49.47(2.913)$ & $35.15(1.312)$ \\
Weight, mean (SD) gram & $35.58(1.563)$ & & 0.461 \\
Length, mean (SD) cm & & & 0.802 \\
Head circumference, mean (SD) cm & $5727.00(843.171)$ & $5494.74(1092.410)$ & 0.559 \\
& $60.31(2.738)$ & $60.08(2.844)$ & $39.52(1.952)$ \\
\hline
\end{tabular}

Note: Significant if $\mathrm{p}$ value is $<0,05$, Independent T-test 
Table 4. Differences in the quality of preterm GMs, writhing GMs and fidgety GMs in the massage and control groups

\begin{tabular}{lccc}
\hline \multicolumn{1}{c}{ GMs Period } & Massage & Control & P \\
\hline Preterm GMs, n (\%) & $3(14.3)$ & $7(30.4)$ & $0.287^{(1)}$ \\
$\quad$ Normal & $18(85.7)$ & $16(69.6)$ & \\
Abnormal & & & $0.150^{(2)}$ \\
Writhing GMs, n (\%) & $7(35.0)$ & $12(63.2)$ & \\
$\quad$ Normal & $13(65.0)$ & $7(36.8)$ & $1.000^{(1)}$ \\
$\quad$ Abnormal & & & \\
Fidgety GMs, n (\%) & $15(75.0)$ & $15(78.9)$ & $4(21.1)$ \\
$\quad$ Normal & $5(25.0)$ & &
\end{tabular}

The quality of preterm GMs in massage group (85.7\%) and control group $(69.6 \%)$ with $\mathrm{p}=0.287$. The quality of GMs writhing in the massage group was dominated by abnormal GMs (65\%), in not massage group were dominated by normal $(63.2 \%)$, with $p=0.150$. In the fidgety GMs, the massage group (75\%) and control group $(78.9 \%)$ were dominated by normal GMs, with $\mathrm{p}=1.000$ (Table 4$)$.

\section{DISCUSSION}

In this study, the education of undergraduate mothers in massage group was higher than control group $(p=0.007)$ (Table 1). Education and income levels are strong indicators in describing socio-economic status and predicting family health status (Joseph et al 2014). The level of education can determine the mindset and understanding of parents on how to educate and care for children, the selection of quality and quantity of nutritional intake. Good parenting factors have an impact on children's growth and development (Blumenshine et al 2011).

Preterm infants should be screened early, early intervention after birth. The initial intervention can be carried out by the NICU, such as massage, touch, multisensory stimulation. This is a simple, economical, effective and useful thing in improving the quality of the premature baby (Ma et al 2014, Bouwstra et al 2003). Exclusive breastfeeding given at least 6 months shows optimal quality GMs (healthy infant population age of 3 months) (Bouwstra 2003).

This study, increased body weight in both groups with a mean increase in body weight in massage group $(5727.00(843,171)$ grams) and control group (5494.74 $(1092,410)$ grams $)(\mathrm{p}=0,461)$ (Table 3). Preterm infant will lose about $10-15 \%$ of weight in the first week of birth. To assess the growth and adequacy of nutrition targets the speed of increase between 15-20 grams $/ \mathrm{kg} /$ day, $1 \mathrm{~cm}$ increase in length/week and head circumference 0.5-1 cm/week (Deirdre and Diane, 2012). Massage stimulation has an effect on weight gain by increasing insulin (increasing glucose conversion for both short and long-term storage) and IGF-1 (stimulating cell growth), reducing cortisol levels and increasing vagal activity, increasing body weight by reducing the effect of cortisol inhibition on insulin secretion (Field et al 2008).

The quality of preterm GMs in massage and control groups did not differ significantly, $\mathrm{p}=0.287$ (Table 4). Preterm infants are at risk of disruption of efferent motor connections between subplate-cortex and spinal caused by disruption of cortical subplate formation and white matter damage due to a breakdown of premature gestation (Algra 2007). Abnormal GMs occur due to subplate cortex damage or dysfunction or connective tissue that runs descending through the area of white matter (Kostovic \& Jovanov-Milosevic 2006). Pathological conditions of prenatal, perinatal and postnatal periods can show abnormal GMs, such as maternal diabetes, maternal hypertension, premature of rupture membranes, dexamethasone therapy during the neonatal period and administration of antenatal antiepilepsy drugs (Bos et al 1998), asphyxia and neonatal hyperbilirubinemia (Prechtl 1993) also low birth weight (Suryawan et al 2008).

In this study, writhing GMs was carried out at almost the same gestational age, and no significant difference was found in the two groups $(p=0,150)$ (Table 4). The beginning of the writhing GMs period begins at 36-38 weeks PMA, where the subplate will experience a broad period of shrinkage through a process that runs parallel and along with the growth of the callosal and corticocortical area in the cortex (Kostovic \& JovanovMilosevic 2006). In this period, the behavior status of the baby can be clearly assessed and the disappearance of the wave image of slow activity on preterm EEG (Vanhatalo et al 2005). Subsequent developments will 
be strongly associated with changes in the function of gaminobutyric acid (GABA) which was originally excitatory to be inhibitory (Vanhatalo et al 2005). The glutamate system describes developmental changes between weeks 36-38 PMA to post-6-8 weeks, where cortical-glutamate receptors experience transient overexpression (Vanhatalo et al 2005).

In this study, fidgety GMs were performed at almost the same gestational age, massage group at 55.55 gestational age (SD 1,731) weeks and control group at 55.32 gestational age (SD 1,600) weeks, no differences were found between massage group and control group, with a value of $p=1,000$ (Table 4) In the fidgety GMs period changes occur in the membrane of the central nervous system neurons, changes in the intervention of muscles (regression of poly-neural muscle innervation), changes in spinal circuits (increased effect of Renshaw inhibition) and changes in supraspinal level organization (Hadders-Algra \& Prechtl 1992). Absolute abnormal GMs in the fidgety period (2-4 months post term) were able to predict cerebral palsy with an accuracy rate of 85-98\% (Hadders-Algra \& Groothuis 1999).

Precthl et al (1993) stated that the importance of quality GMs during fidgety period because $69 \%$ of normal GMs can show normal neurological outcome, abnormal GMs show 98\% abnormal neurologists (82\% cerebral palsy and $13 \%$ minor neurological sign). Abnormal absolute fidgety GMs are at risk of MND, ADHD and cognitive related problems, if cerebral palsy does not occur. Mild mild fidgety $\mathrm{GMs}$ at risk of $\mathrm{MND}, \mathrm{ADHD}$ and aggressive behavioral disorders (Hadders-Algra \& Groothuis 1999).

GMs are produced by central pattern generators (CPG) located in the brain stem, corticospinal or reticulospinal tracts, where damage to CPG can provide an abnormal picture of GMs (Einspieler \& Prechtl, 2005). The brains of preterm infants are immature, have strong plasticity, thus requiring early intervention can improve the quality of GMs to reduce or prevent injury from $\mathrm{CPG}$, the corticospinal tract or the reticulospinal tract (Ma et al., 2014).

Abnormal-quality GMs at 3 months post term are associated with a variety of conditions (premature birth, IUGR, hyperbilirubinemia, Down syndrome, and nonoptimal LCPUFA pre- and post-natal status (Bouwstra, 2003). Abnormal GMs show an association with the area of white matter in the neocortex area, the descending connection to the spinal majority must go through the internal and basal ganglia capsules in the periventricular white matter area (Guzetta et al., 2003).

\section{CONCLUSION}

The quality of preterm GMs, writhing GMs and fidgety GMs for preterm infants were not significantly differences in both groups.

\section{ACKNOWLEDGMENT}

We would like acknowledge to Hari Basuki Notobroto, $\mathrm{MD}, \mathrm{PhD}$ who support statistical analysis in this study.

\section{REFERENCES}

Algra M (2007). Putative neural substrate of normal and abnormal general movements. J Neo Bio Rev. 31: 1181-1190.

Anderson P, Doyle LW (2003). Neurobehavioral outcomes of school age children born extremely low birth weight or very preterm in the 1900s. JAMA. 289: 3264-3272.

Blumenshine PM, Egerter SA, Libet ML, et al (2011). Father, Äôs Education: An Independent Marker of Risk for Preterm Birth. Matern Child Health J. 15: 60-67.

Bos AF, Martijn A, Okken A, et al (1998). Quality of general movements in preterm infants with transient periventricular echodensities. Acta $\mathrm{P} \sqrt{ } \boldsymbol{q}$ diatr. 87:328335.

Bouwstra H, Dijck-Brouwer DAJ, Wildeman JAL, et al (2003). Long-chain polyunsaturated fatty acids have a positive effect on the quality of general movements of healthy term infants. Am J Clin Nut. 78:313-318.

Deirdre E, Diane MI (2012). Nutrition. Dalam: Cloherty JP, Eichenwald EC, Stark AR. Editor. Manual of Neonatal Care. Edisi ke-7. Lippincott William Wilkins; Philadelphia: pp 114-136.

Diego M, Field T, Hernandez-Reif M, et al (2007). Preterm infant massage elicits consistent increases in vagal activity and gastric motility that are associated with greater weight gain. Acta Pediatr. 96: 15881591

Einspieler C, Prechtl HFR (2005). Prechtl's assessment of general movements : A diagnostic tool for the functional assessment of the young nervous system. Ment Retard Dev Disabil Res Rev. 11: 61-67.

Field T (2014). Massage theraphy research review. Complement Ther Clin Pract. 20; 224-229.

Field T, Diego M, Hernandez-Reif M, et al (2008). Insulin and Insulin-Like Growth Factor-1 Increased in Preterm Neonates Following Massage Therapy. J Dev Behav Pediatr. 29: 463-466.

Guzetta A, Mercuri E, Rapisardi G (2003). General movements detect early signs of hemiplegi in term 
infant infant with neonatal cerebral infarction. Neuropediatr. 34: 61-66.

Hadders-Algra M (2004). General movements: a window for early identification of children at high risk for developmental disorders. J Pediatr.145: 512518.

Hadders-Algra M, Groothuis AMC (1999). Quality of general movements in infancy is related to neurological dysfunction, ADHD, and aggressive behaviour. Dev Med Child Neurol. 41: 381-391.

Hadders-Algra M, Precthl HFR (1992). Developmental course of general movements in early infancy, I: descriptive analysis of change in form. Early Hum Dev. 28: 201-214.

Joseph KS, Fahey J, Shankardass K, et al (2014). Effects of socioeconomic position and clinical risk factors on spontaneous and iatrogenic preterm birth. Pregnancy Childbirth. 14: 1-6.

Khan OA, Garcia-Sosa R, Hageman JR, et al (2014). Core concepts-neonatal neurological examination. Neo Reviews. 14: 316-324.

Kostovic, Jovanov-Milosevic (2006). The development of cerebral connections during the first 20-45 weeks, Äô gestation. Semin Fetal Neonatal Med. 11: 415-422.

Lee H (2005). The effect of infant massage on weight gain, physiological and behavioral responses in premature infants. J Korean Acad Nurs. 35: 14511460.

Ma L, Yang B, Meng L, et al (2014). Effect of early intervention on premature infants, Äô general movements. Brain Dev. 37: 387-393.

Precthl HFR, Ferrari F, Cioni G (1993). Predictive value of general movements in asphyxiated fullterm infants. Early Hum Dev. 35: 91-120.

Suryawan A, Permono B, Witarini KA, et al (2008). Assessment of the quality of general movements in newborn infants: a tool to predict developmental disorders at an early age. Paediatr Indones. 48:292298.

Suryawan A, Witarini KA, Etika R, et al (2008). Evaluasi Penggunaan Metode Prechtl untuk Menilai Kualitas Gerakan Spontan Bayi Muda Sehat: Pengalaman RSU Dr. Soetomo Surabaya. Sari Pediatri. 9: 363-369.

Underwood MA (2013). Human milk for the premature infants. Pediatr Clin N Am. 60:189-207.

Vanhatalo S, Voipio J, Kaila K (2005). Full-band EEG (FbEEG): an emerging standard in electroencephalography. Clin Neurophysiol. 116: 18.

WHO (2012). March of Dimes, Partnership for Maternal, Newborn \& Child Health, Save the Children. Born too soon: the global action report on preterm birth. 